TASK FORCE REPORT JUNE 1971

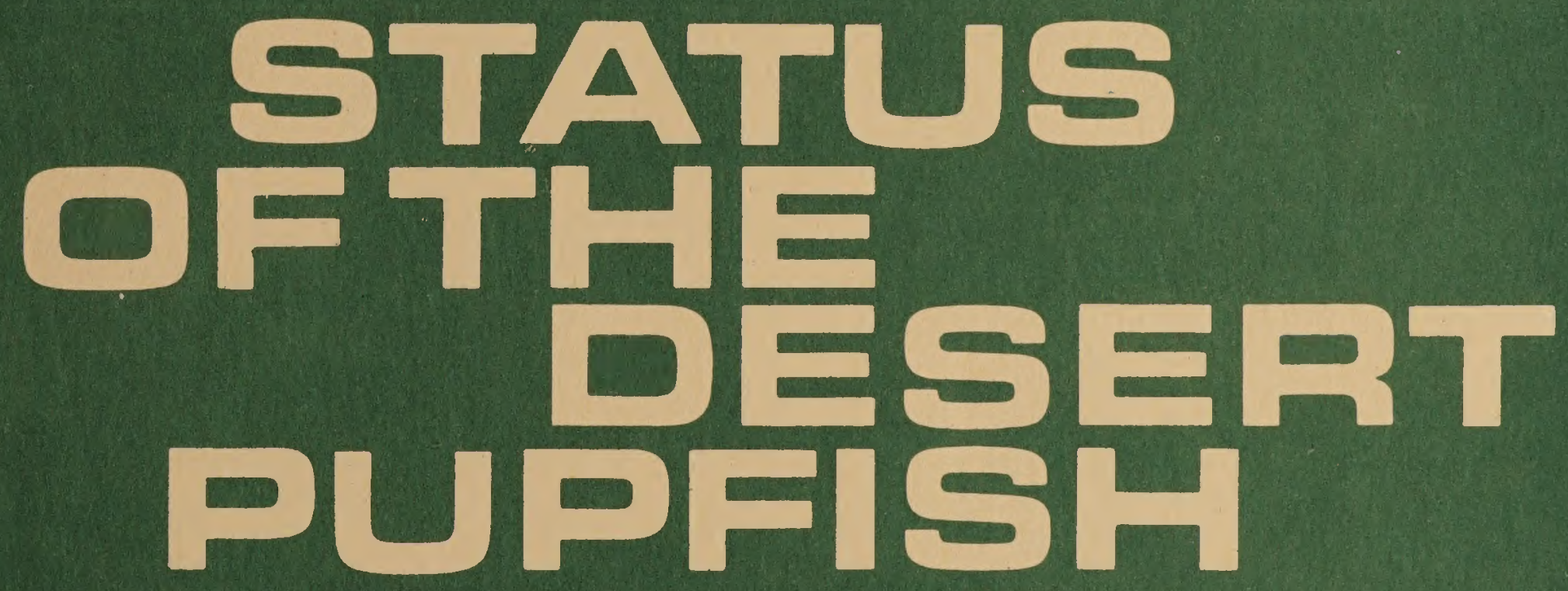

U.S. DEPARTMENT OF THE INTERIOR 
Fish drawings by Craig P. Phillips, National Fisheries Center and Aquarium, Washington, D.C. 


\section{STATUS OF THE DESERT PUPFISH}

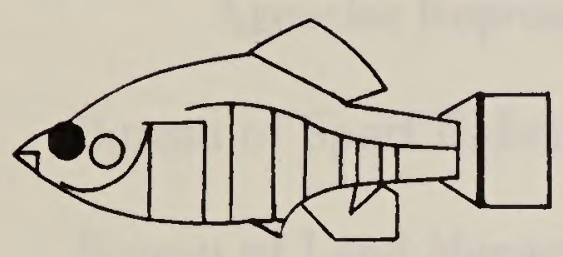

OWENS PUPFISH, Cyprinodon radiosus.

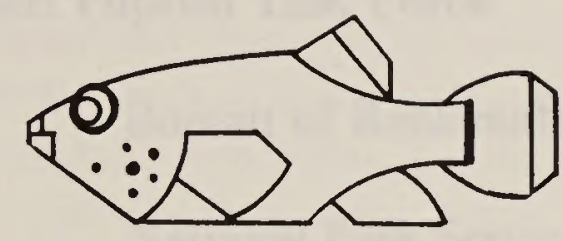

DEVILS HOLE PUPFISH, Cyprinodon diabolis.

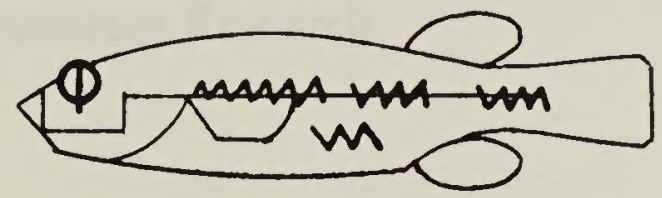

PAHRUMP VALLEY KILLIFISH,

Empetrichthys latos latos.

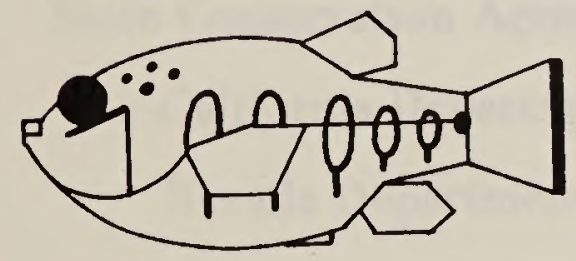

WARM SPRING PUPFISH,

Cyprinodon nevadensis pectoralis.

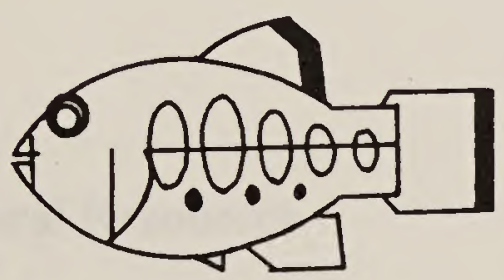

TECOPA PUPFISH,

Cyprinodon nevadensis calidae. 
3HT 70 2\%T.AT2 H217949 799239. 
A Progress Report on the

\section{STATUS OF THE DESERT PUPFISH}

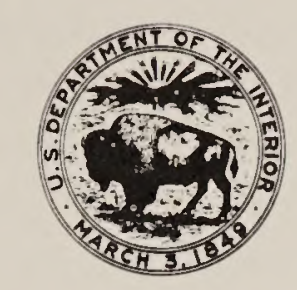

Agencies Represented on the Interior Desert Pupfish Task Force

Bureau of Sport Fisheries \& Wildlife

Bureau of Reclamation

Bureau of Land Management

National Park Service

Office of the Solicitor

Geological Survey

Office of Water Resources Research

\section{Task Force Cooperators}

State Conservation Agencies:

California Department of Fish and Game

Nevada Department of Conservation and Natural Resources

Nevada Department of Fish and Game

\section{Universities:}

University of California at Los Angeles

University of Nevada at Las Vegas

University of Michigan, Ann Arbor

The Desert Fishes Council

Advisory Group 



\section{FOREWORD}

The plight of tiny pupfishes, isolated in scattered springs and streams of the Death Valley System of California and Nevada for thousands of years, is a matter of national and even international concern. For some forms concern comes too late-they have already become extinct. The very existence of others is threatened by activities of man-appropriation of spring and ground waters, destruction of habitats, use of pesticides, and release of exotic species into these restricted aquatic habitats. In a brief span of several months or a few years at most, these species, too, may disappear if protective measures are not implemented immediately.

A Task Force has been appointed within the Department of the Interior to devise and to immediately apply appropriate action required to save the pupfishes. In this cooperative endeavor, the Department is working in close coordination with interested State, academic, and private agencies and individuals.

This is a Task Force report on the status of these unique fishes and an account of what has been done, what is being accomplished, and what must still be undertaken through united efforts to perpetuate these scientifically significant elements of America's natural heritage.

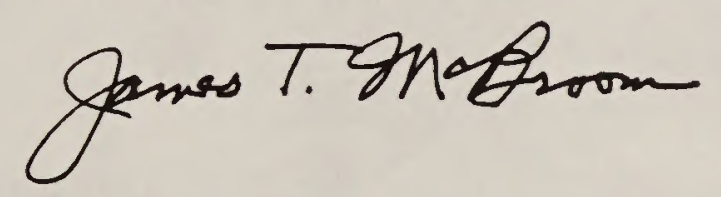

Chairman, Departmental

Pupfish Task Force 



\section{STATUS OF THE DESERT PUPFISH}

\section{WHAT ARE PUPFISH?}

Pupfish are diminutive fishes (eyprinodonts) no longer than one's little finger, but they have scientific importance far greater than their size. The desert pupfish represent remains of larger populations that once inhabited the ancient lakes of the Southwest. As the lakes dried and deserts appeared they adjusted to living in reduced habitats where unusual and extreme conditions exist. Fishery scientists believe five of the living forms of pupfish are presently endangered; one other may already be extinct. These unique fish are examples of evolutionary change of the most dynamie type, and immediate effective measures are needed to perpetuate them.

They are aggressive to other fishes and to each other. Males are colorful, with irideseent blues and purples on their backs and sides, and with black bars and dark fin cdges. Females are mottled brown, and usually smaller and slimmer than the malcs. Pupfishes are omnivorous feeders-algae, plankton, insects, and smaller fishes, alive and dead. They live in water ranging from near freczing temperatures to well over 100 degrees Fahrenheit. Some can survive in waters that are up to six times saltier than sea water. They can live in small pockets, deep holes, and under very adverse and limited conditions.

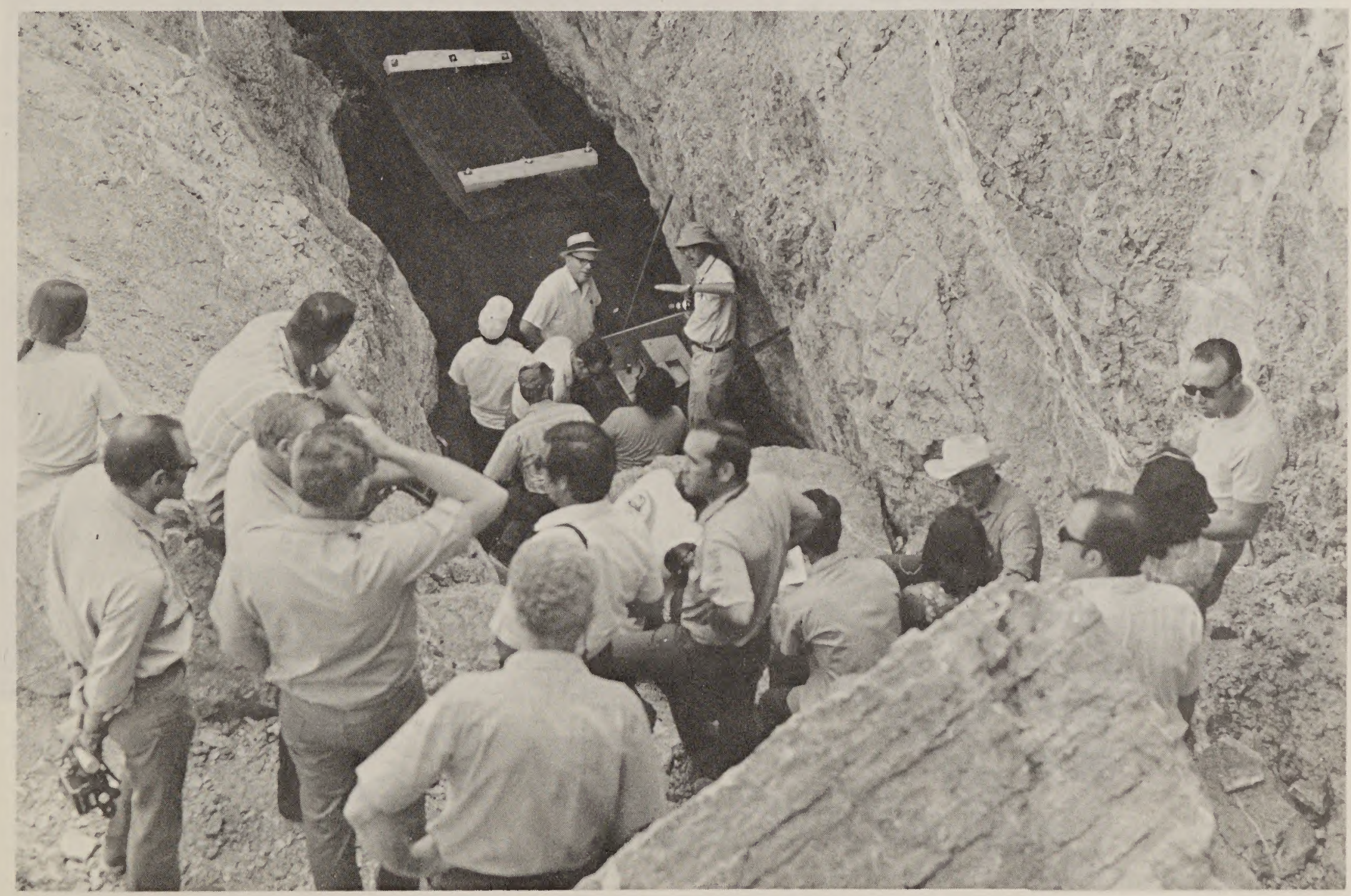

Participants in the Second Symposium on "Rare and Endangered Fishes of the Death Valley System" examining Devils Hole, habitat of the Devils Hole pupfish. The artificial shelf is in the background and the water level recorder is in the foreground. Photo-P. Sanchez, National Park Service 
Of the surviving Death Valley eyprinodonts, five species and six subspecies are recognized. These belong to two genera, one of which has only one species. Three kinds of these fishes have recently become extinet, primarily because their spring habitats have ehanged or have been destroyed. One other may be extinet. We must save the environment if these fish are to survive. Onee gone, they eannot be replaced. Except for Devils Hole, a detached part of Death Valley National Monument, and Sehool Spring, most of the springs are in private ownership. Some of the springs receive limited protection but most are threatened with destruetion by oversubseribed pumping of ground water.

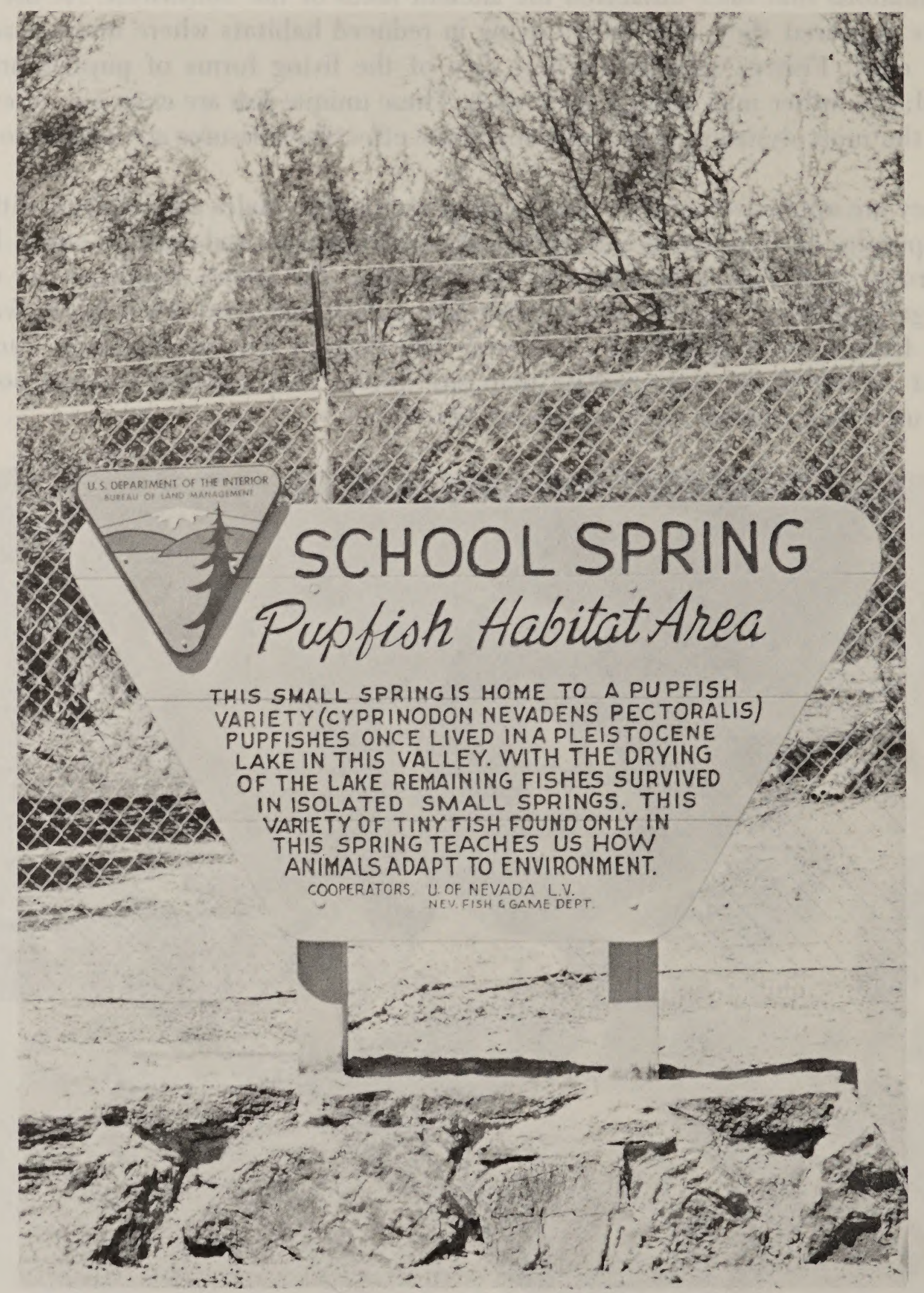

Entrance sign at the School Spring Refuge for the Warm Spring pupfish. Photo-J. Yoakum, Bureau of Land Management 


\section{WHAT ARE THE PROBLEMS?}

There has been a shrinkage in the surface waters of the Death Valley drainage system within the last decade. Almost all water in this desert country comes from underground except during periods of heavy runoff. Surface exposure is confined to deep holes and seeps. It is in these precarious environments that the pupfishes still survive. Man has jeopardized the existence of these fishes by several actions:

1. By introducing predatory and competitive fishes such as the largemouth bass, mosquitofish, exotic tropicals, goldfish, and even bullfrogs.

2. By destroying the habitats through drainage, filling, land clearing and leveling, and by diversion of surface waters for irrigation.

3. By pumping water from springs and underground aquifers resulting in accelerated decline of pool levels.

4. By the use of pesticides and other chemicals that find their way into springs, thereby threatening an entire fish population.

5. By overzealous collecting of pupfishes for various purposes.

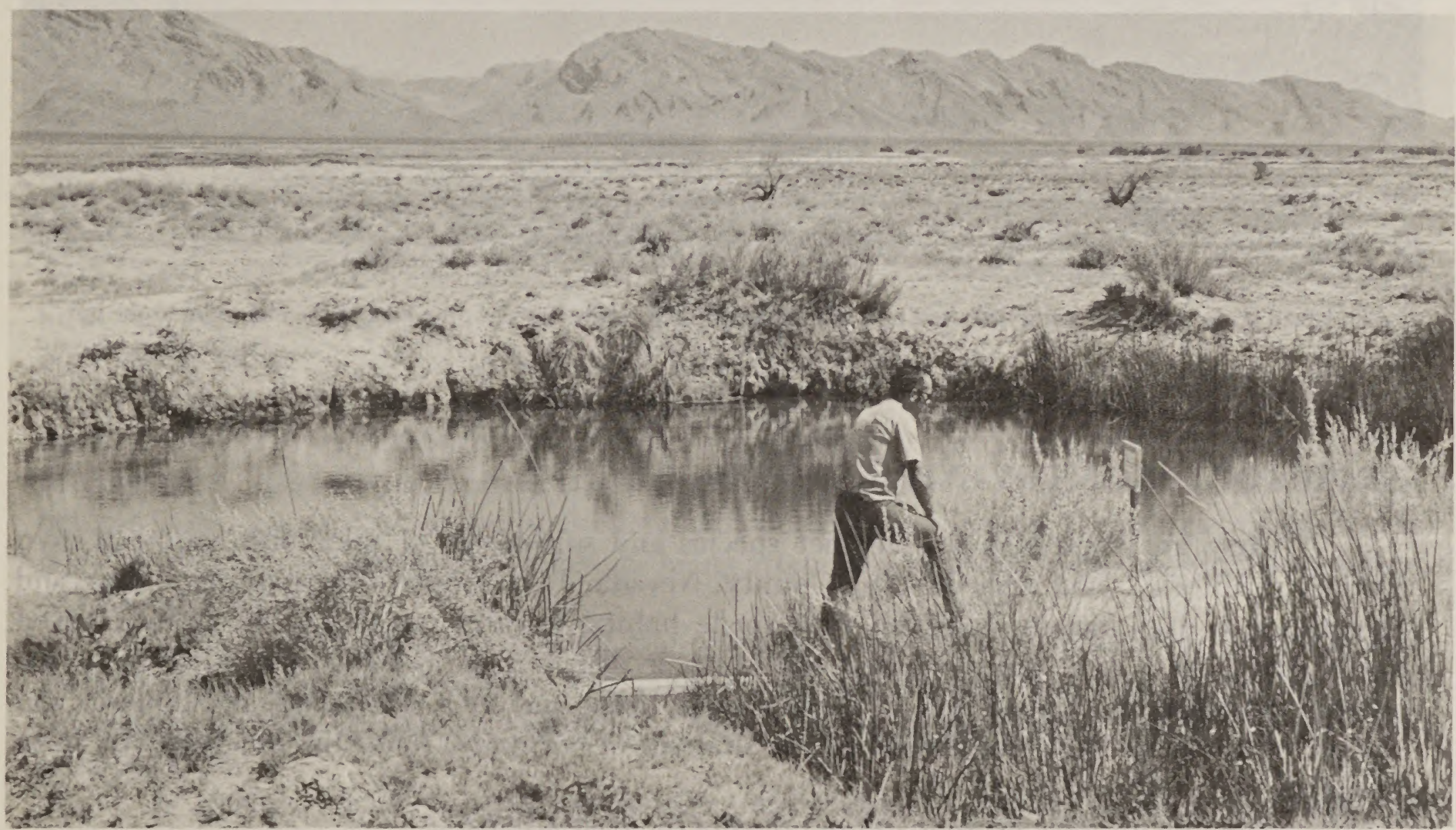

Big Spring is one of the largest springs in Ash Meadows and would provide excellent pupfish habitat except that it contains several kinds of exotic fishes.

Photo-C. H. Lostetter 


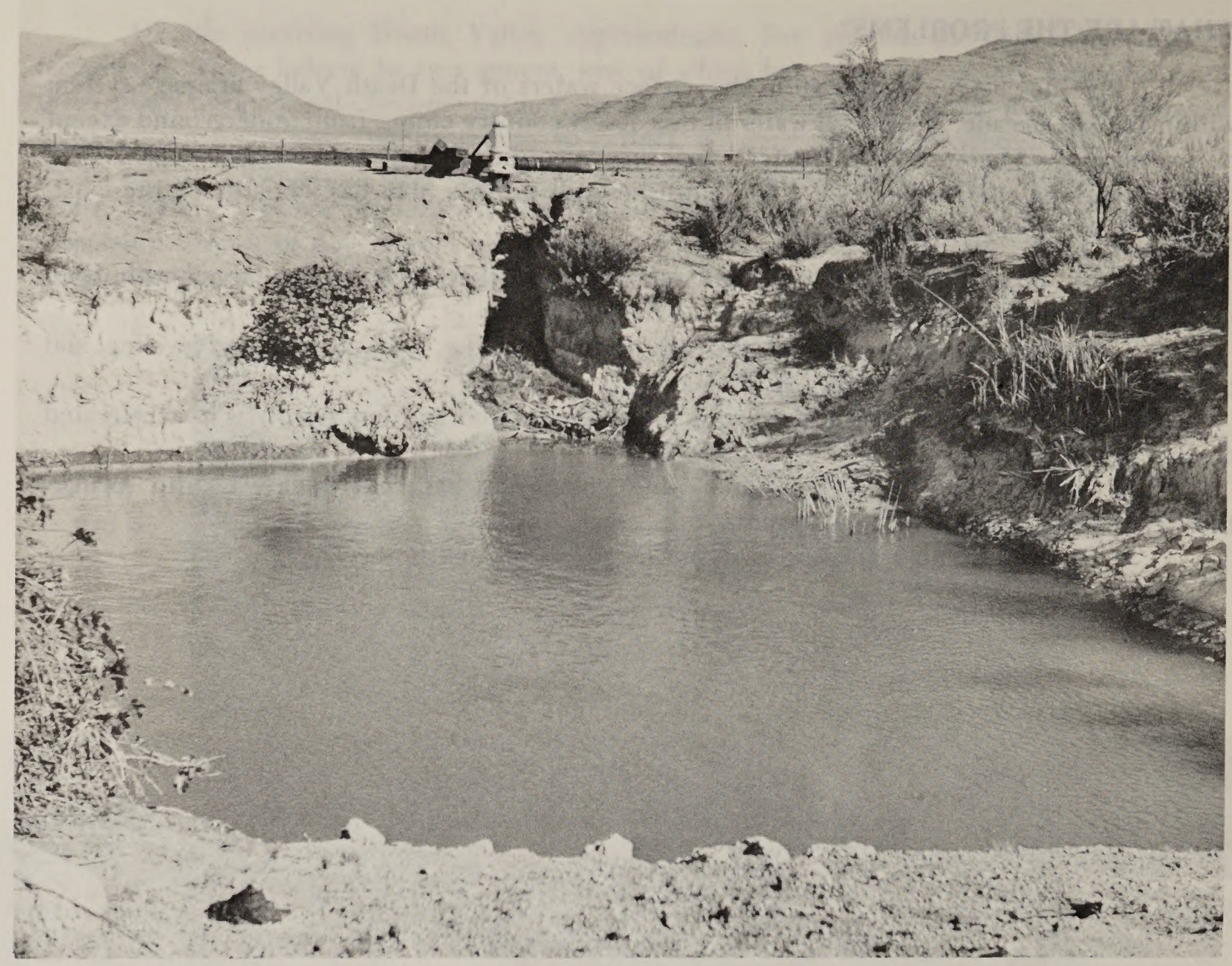

An unamed spring with pump and irrigation pipe in the background. Devils Hole is at the base of the mountain to the left of the pump.

Photo-Dale Lockard

\section{STATUS OF THE DESERT CYPRINODONTS}

There are 10 recognized distinct species and subspecies of these fish found in Inyo County, California, and adjacent Nye County, Nevada. They inhabit desert springs, seeps, and streams with cach variety confined to a single habitat in most instances. The fishes evolved from stocks that were more widespread in their distribution and less diversified than the present populations. Knowledge of these unique fishes and their habitats is still limited, and danger of their being lost as unique representatives of our native fauna has only recently been realized.

Three forms have become extinet during the past 23 years:

Raycraft Ranch springfish, Empetrichthys latos concavus. Formerly occurred in Pahrump Valley, Nye County, Nevada. The habitat was destroyed in 1955.

Pahrump Ranch Killifish, E. 1. pahrump. Occurred in Pahrump Valley, Nye County, Nevada. The habitat was destroyed in 1955.

Ash Meadows springfish, E. merriami. Oecurred in the Death Valley System. The last specimen was taken in 1948. 
Another subspecies has been reduced to such a low population level that it may also be extinct. The Shoshone pupfish, Cyprinodon nevadensis shoshone is found in a few springs near Shoshone, California, on private land. Further studies are being made to determine its status.

The following species are classified as ENDANGERED by the Secretary of the Interior and unless protective and restorative measures are promptly initiated they also will become extinct:

DEVILS HOLE PUPFISH, Cyprinodon diabolis-Most of the world's population of the tiny Devils Hole pupfish dwells in the confines of a small, warm pool in Devils Hole. The site is located in a detached portion of Death Valley National Monument in Ash Meadows, Nye County, Nevada. This sanctuary was established by Presidential Proclamation in 1952 and is administered by the National Park Service.

The ancestral form of this pupfish became isolated more than 20,000 years ago in Devils Hole when the once extensive lake system of the Death Valley region of Nevada and California began to dry up and recede. In this isolated waterhole, the fish evolved rather rapidly into an entirely unique inch-long species, highly adapted to the unusual conditions of its restricted, hot water environment.

The pool, only 50 feet long and 10 feet wide, is found 50 feet below the rim of Devils Hole. It has neither a surface inlet nor outlet but is connected to a vast underground water system.

At one end of the pool is a small, submerged shelf which measures 10 feet wide and 18 feet long. The critical existence of the pupfish depends upon maintaining the water level above this shelf, for on it the entire population feeds and reproduces. Beyond the shelf, the water drops precipitously into a cavern more than 284 feet deep.

Sun rays that stimulate growth of algae strike the water surface in the deep crevasse for only brief periods during summer days. Algae is important as food for the pupfish and for aquatic organisms upon which they feed. Under conditions of abundant food and optimum water level, the population of pupfish may increase to 700 individuals by fall. In winter, however, when sunlight cannot reach the water, food supplies become scarce and total numbers of the Devils Hole pupfish may diminish to less than 200.

Recently, the water level in Devils Hole has been dropping drastically. If it continues to decline, more of the vital shelf area will be uncovered. For the lack of suitable spawning and feeding sites, this unique species could then become extinct. Preservation of this strategic habitat is the primary objective of the Department's efforts to insure the survival of the Devils Hole pupfish. Other interim measures are being attempted to preserve the breeding population of this relict species.

In May 1970, an artificial shelf and an electric lighting system were installed in Devils Hole. During subsequent months, the pupfish utilized the shelf for feeding and the lights stimulated growth of aquatic vegetation. As yet, there is no evidence of breeding on the artificial shelf.

In addition, small numbers of pupfish were transplanted into two isolated springs and into a man-made pool constructed nearby to simulate conditions in Devils Hole. Efforts are being made to reproduce the pupfish in captivity. It is too early to determine the success of these activities.

TECOPA PUPFISH, Cyprinodon nevadensis calidae-This pupfish has been found only in a reservoir and a small stream near Tecopa Hot Springs about 7 miles south of Shoshone, California. In this same hot springs complex there is a public bath house, a laundering facility and a large trailer park, and there is evidence of interest in further development of the area. This pupfish is in an extremely vulnerable situation. 


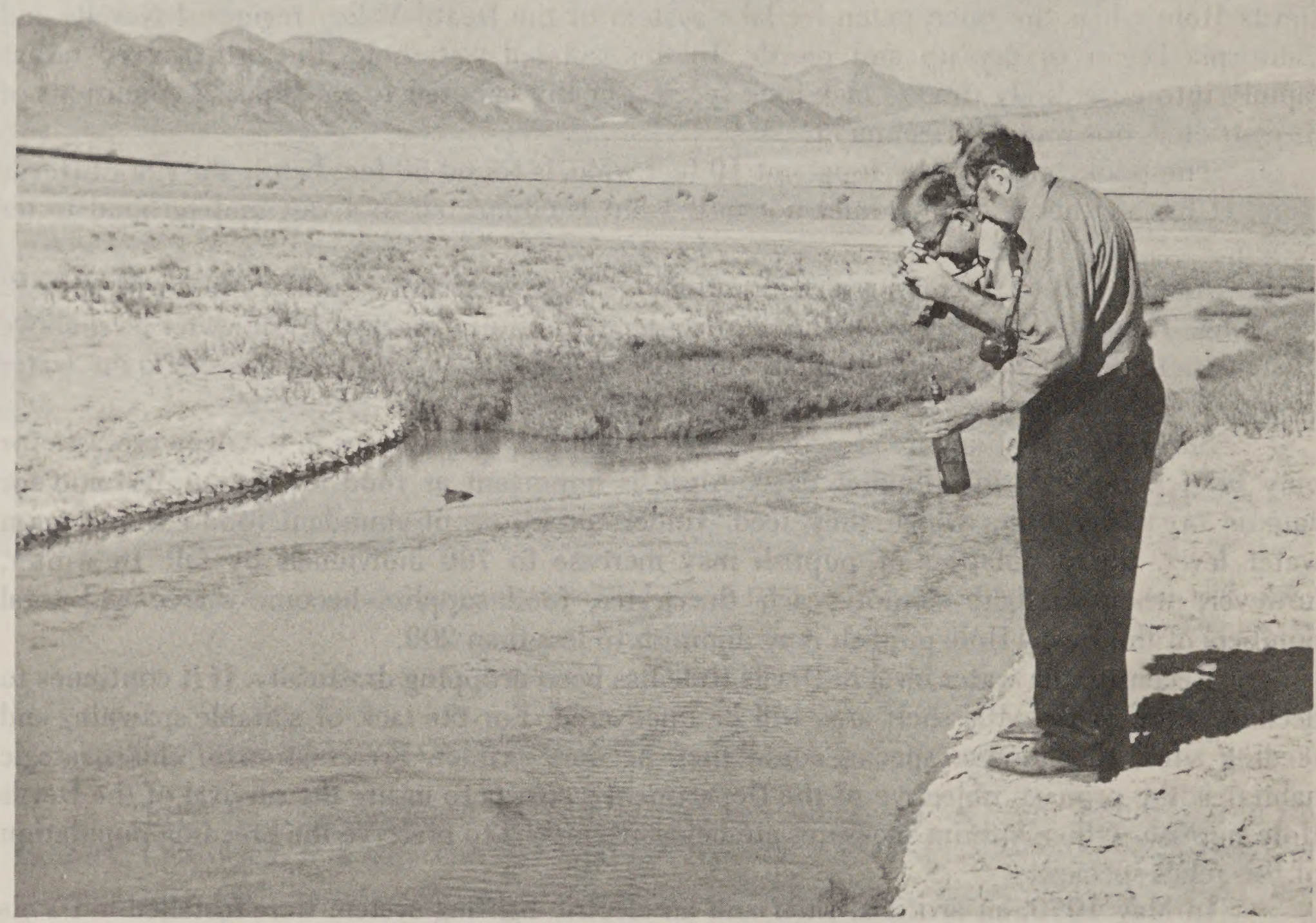

One of the Tecopa Hot Springs.

Photo-C. H. Lostetter

WARM SPRING PUPFISH, Cyrinodon nevadensis pectoralis-Its present distribution is limited to School Spring and Scruggs Springs in the northern part of Ash Meadows, Nye County, Nevada. Sehool Spring, whieh is under the administration of the Bureau of Land Management, has been improved and is protected by a chain link fence. The natural water supply is dwindling. A well was drilled nearby and a pump installed for supplementary water supply. A seareh is underway for suitable transplant sites in Nevada to support reserve populations of this pupfish.

OWENS PUPFISH, Cyprinodon radiosus-Onee widely distributed in Owens Valley of California, the species is now confined primarily to a marshy pool located about 10 miles 
north of Bishop, California. Here in eooperation with the Los Angeles Department of Water and Power, the California Department of Fish and Game has established a native fish sanetuary for the perpetuation of this pupfish. To further insure the survival of the species, Owens pupfish have been transplanted also into a few additional nearby loeations.

PAHRUMP KILLIFISH, Empetrichthys latos-Native population of this species is found in a small pool loeated on a private raneh in Pahrump Valley, Nye County, Nevada. Declining water levels and potential adverse aetivities in this vicinity threaten this species' existenee. Consequently, a few of these killifish were transplanted into an isolated spring in southern Nevada in an attempt to protect these fishes if they were lost from their original habitat.

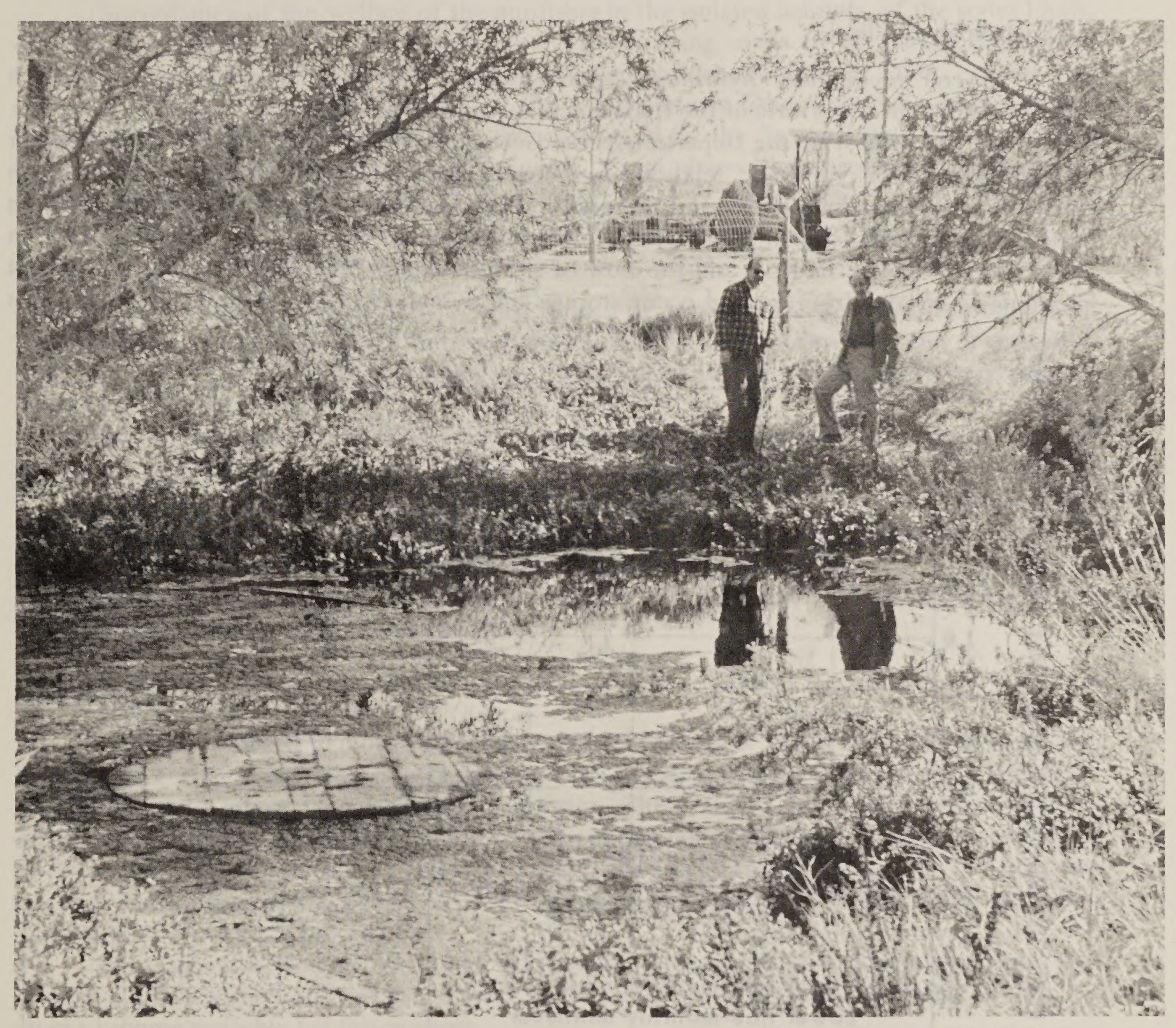

Pool at Manse Springs, Pahrump Valley, Nevada, habitat of the Pahrump killifish. 
The following five other species or subspecies are not presently classified as endangered. However, they are by no means safe and close monitoring of these populations is necessary to assure their continued existence.

AMARGOSA PUPFISH. Cyprinodon nevadensis amargosa ASH MEADOWS PLPFISH, Cyprinodon nevadensis mionectes SARATOGA SPRINGS PLPFISH, Cyprinodon nevadensis nevadensis SHOSHONE PUPFISH, Cyprinodon nevadensis shoshone (S̀tatus Undetermined) SALT CREEK PUPFISH, Cyprinodon salinus

\section{WHAT ELSE WAS OR IS BEING DONE?}

\section{Hydrologic Studies.}

Several preliminary hydrologic appraisals and two major investigations have been instituted through the efforts of the Departmental Pupfish Task Foree.

At the request of the Department, the Geological Survey has initiated an investigation to determine the hydrologic relationship between ground water withdrawals in the Ash Meadows area, spring discharge, and the pool level in Devils Hole. This investigation is now in progress and has as its main objectives the determination of effeets of pumping from wells on the water level in Devils Hole and the flow of springs; to determine what part of the current pumping is derived from ground water storage and reduction in spring discharge rather than

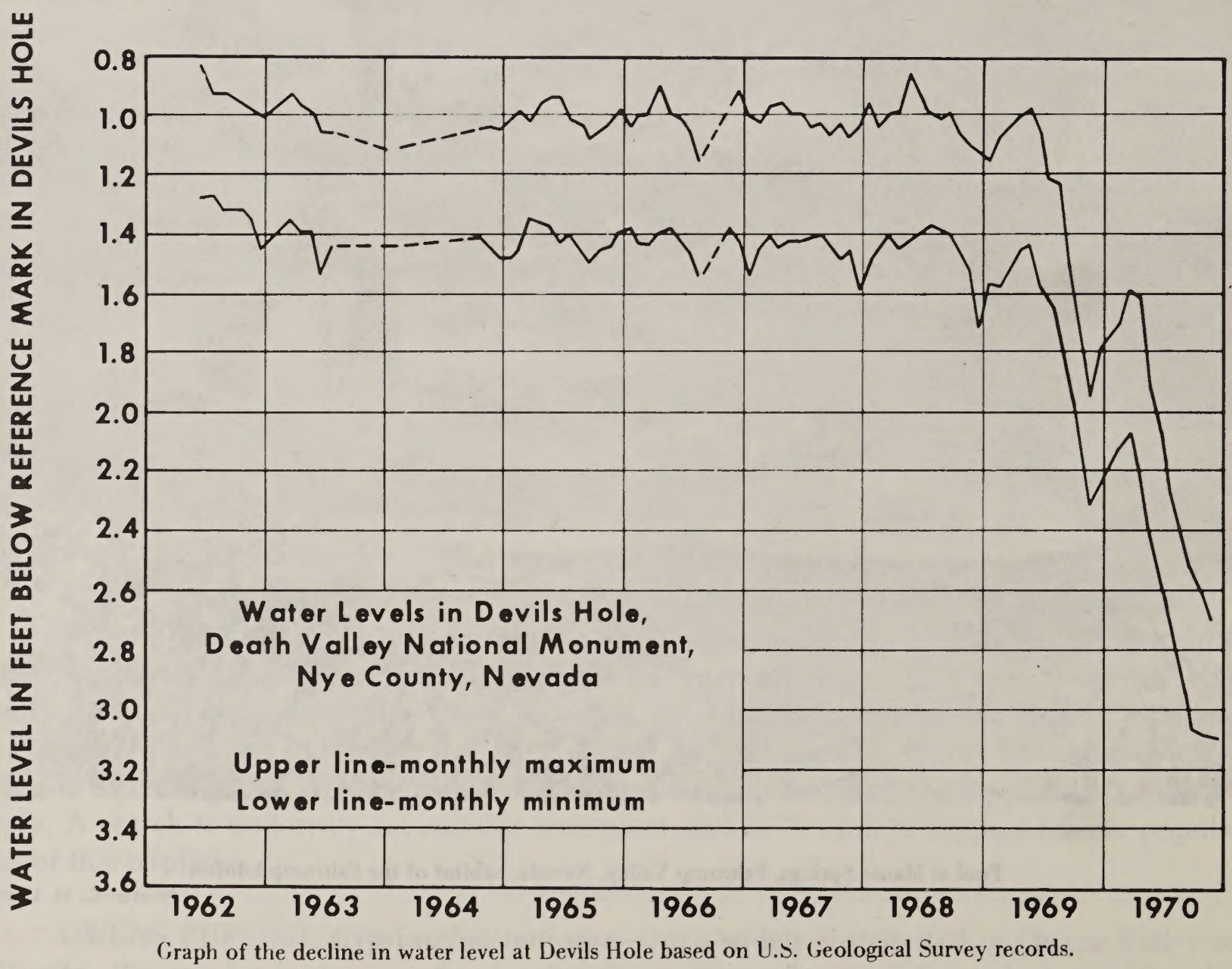


from salvage of evaporated and transpired water; and, to evaluate other possible causes of the decline in water level in Devils Hole. Funding is provided by the Department's Bureau of Sport Fisheries and Wildlife, Bureau of Land Management, Bureau of Reclamation, National Park Service, and Geological Survey.

A second study, funded by the Department's Office of Water Resources Research and contracted to the Nevada Desert Research Institute, is just beginning (February 1971). It is a logieal step following the Geological Survey's hydrologic studies, and has as its purpose the formulation of a water-development and management plan for the Ash Meadows basin that would ensure the safety of the pupfish.

\section{Surveillance}

Surveillance of the welfare of the pupfishes in the isolated habitats, of the water levels, of food conditions, and of endangering activities is being made by all parties concerned. Periodic examination of fish populations and water conditions are made by State. Federal, and university officials. Weckly inspections of the Ash Meadows fishes and their environments, including School Spring and Devils Hole, are conducted by the National Park Service, Bureau of Land Management, and the Geological Survey. These observations are reported directly to the Task Force.

\section{Additional Transplant Sites and Refugia}

In an attempt to perpetuate various species of pupfishes in the event disaster should befall endemic populations in the natural habitats, additional locations are being investigated that may scrve as suitable sites in which to transplant certain species or which may serve as refugia for endangered forms.

Suitable locations are those which contain biological, physical, and chemical aquatic conditions that nearly duplicate those found in the natural environment of the species to be transplanted. Moreover, such locations must not contain any closely related species. The transplant or refugia sites must be secure from adverse uses that might threaten the survival of the transplanted fishes, and they must contain reliable water supplies.

All agencies concerned with the survival of the pupfishes are participating in the location and cvaluation of potential sites.

\section{Aquarium Culture}

Sinee it has been demonstrated that eertain Cyprinodon species and related forms can be bred and reared in captivity, the Task Force endorses the program of establishing "standby" aquarium stoeks of endangered pupfish species. These stocks should be protected from intentional or accidental hybridization with one another, since this would make them valueless in restoeking wild populations. Rearing of captive specimens could be allocated to a very few selected institutions, public aquariums, or responsible individuals under prescribed, controlled eonditions.

It is anticipated that, for public information and appreeiation purposes, a display of certain pupfish speeies will be established at the National Aquarium in Washington, D.C., if stocks become available for this purpose.

\section{Reclassification of Bureau of Land Management Lands}

Approximately 7300 acres of public lands in Ash Meadows have been 'de-classified' for exchange to private ownership by Secretarial Order as of September 3, 1970. These lands do 
not now have any pending application for transfer of ownership. The Task Force has recommended that no new classification actions be taken until all the hydrologic information has been analyzed and definite conclusions reached on the ground water system.

\section{Present Legal Status}

In withdrawing Devils Hole from the public domain for inclusion in Death Valley National Monument, the 1952 Presidential Proclamation stated that "the said pool is of such outstanding scientific importance that it should be given special protection. .. ." The "peculiar race of desert fish" was cited by the proclamation as a primary reason for protecting the area. Besides the pupfish found in Devils Hole, other species are found in several springs located on the public domain and on certain private lands. The Task Force is approaching this problem on the basis that the Government has a water right in Devils Hole and in the springs located on the public domain.

In addition to the proclamation adding Devils Hole to the National Monument, Congress has enacted the Endangered Species Act which pledges the United States to conserve and protect native fish species where threatened with extinction.

During 1970 water users in the Ash Meadows area filed applications with the Office of the State Engineer, State of Nevada, to appropriate ground water by means of wells. The National Park Service and the Bureau of Land Management, in accordance with Nevada State Statutes, filed protests in opposition to these permits. In October of 1970 the Task Force requested that the State Engineer of Nevada postpone any action on the permits pending completion of ongoing hydrologic studies. In December of 1970, the State Engineer refused to delay the issuance of the permits and held a hearing at which the Department appeared in opposition to the issuance of the water permits. At the conclusion of these proceedings the State Engineer granted the applications and allowed pumping over the objection of the Department. The effect of this action on the water levels in Ash Meadows remains to be seen.

\section{THE NEED FOR CONTINUED COOPERATION}

Much of the planning and effort to date to save the pupfishes has been accomplished by State and Federal agencies and by university scientists. Survival of the fishes depends on the continued cooperation of all these interests.

In November 1969, a group of interested scientists and other conservationists held a Symposium at Death Valley National Monument, California, on the "Rare and Endangered Fishes of the Death Valley System." The primary purpose of the Symposium was to determine what should be done to save these rare and endangered fishes from extinction. A second Symposium was held November 17 and 18, 1970, to review the status of each species, discuss progress during the year and to make future plans.

One outcome of the Second Symposium was the formation of "The Desert Fishes Council," a group dedicated to the preservation of America's desert dwelling fishes. Mr. E. Philip Pister, of the California Department of Fish and Game, was chosen as the first chairman. He is now organizing the Council, which consists of representatives from Government, universities, and others knowledgeable of the environmental problems faced by desert dwelling fishes.

This Council, which will meet on the call of the Chairman, will serve as a clearinghouse for information on all desert fishes. It will have no legal authority, but will be in position to exert an effective influence on State and Federal agencies, private companies and individuals 
on matters related to the fishes and their habitats. Its sphere of operations, initially related to the fishes of the Ash Meadows-Death Valley area, may be expanded to include other geographical areas and kinds of fishes.

The Council Chairman has appointed an Advisory Group to work closely with the Interior Pupfish Task Force on various technical matters. This group is already functioning and has advised the Task Force on such matters as the test pumping schedule (early 1971), plans for fish transplants and refugia, and the need to restrict fish collections in the Amargosa Basin.

Cooperation, however, must go beyond these governmental and scientific groups. Private landowners and citizens, including irrigators pumping water in the Ash Meadows area, have a very important role in the entire preservation effort. It is the pumping and rising requirements for water that affect, perhaps more than any other single factor, the condition of the habitats for the pupfishes and other living inhabitants of the water holes and drainages. Continued participation in these efforts by the Foresta Institute, the Sierra Club, and other private conservation agencies is essential. The interest of the public stimulated by television documentaries, popular articles and news releases, has resulted in hundreds if not thousands of letters urging all possible attention to this environmental crisis. The Task Force, the Desert Fishes Council and all those whose interests are affected by the plight of these small fishes, must sustain their concern and effort if common goals are to be achieved. Time is still of the highest essence. 
THE PEOPLE INVOLVED

\section{U.S. Department of the Interior Pupfish Task Force Members}

Bureau of Land Management

Louis A. Boll

Robert J. Smith

Bureau of Reclamation

E. A. Seaman

Bureau of Sport Fisheries and Wildlife

Harry A. Goodwin

Paul S. Handwerk

Willis King

Edward C. Kinney

James T. McBroom, Chairman

Earl T. Walker

William M. White

Warren J. Wisby

Geological Survey

Gerald Meyer

National Park Service

Edwin W. Reed

O. L. Wallis

Office of the Solicitor

Ronald Lambertson

David A. Watts

Office of Water Resources Research

Stanton J. Ware

The Desert Fishes Council Advisory Group to the Task Force

James H. Brown, Department of Zoology, University of California at Los Angeles

Carl L. Hubbs, Scripps Institute of Oceanography, La Jolla, California

James E. Deacon, Department of Biology, University of Nevada at Las Vegas

Dale V. Lockard, Nevada Department of Fish and Game, Las Vegas

Robert Rush Miller, Museum of Zoology, University of Michigan, Ann Arbor

*E. Philip Pister, California Department of Fish and Game, Bishop

* Chairman, Desert Fishes Council 


\section{SELECTED BIBLIOGRAPHY}

Cry California. 1970. Special report on the pupfish of the Death Valley region. Journal of California Tomorrow, vol. 5, no. 2, Spring 1970, 26 p., 681 Market St., San Francisco 94105.

Deacon, James E. 1969. Fishes of the desert. The Biologist, vol. 22, no. 2 (Dec. 1940), p. 61-69.

LaRivers, Ira. 1962. Fishes and fisheries of Nevada. Nevada Fish and Game Commission, 782 p.

Miller, Robert R. 1948. The cyprinodont fishes of the Death Valley system of eastern California and southwestern Nevada. Miscellaneous Publication, Museum of Zoology, University of Michigan, no. 68, 155 p.

Miller, Robert R. 1961. Man and the changing fish fauna of the American Southwest. Papers, Michigan Academy of Science, Arts and Letters, vol. 46 (1960), p. 365-404.

Pister, Edwin P. 1970. The rare and endangered fishes of the Death Valley system. California Department of Fish and Game, Sacramento. 18 p. plus appendix. Mimco.

\section{FOR ADDITIONAL INFORMATION CONTACT:}

California Department of Fish and Game, 1416 Ninth St., Sacramento 95814

Nevada Department of Fish and Game, Box 10678, Reno 89510

Department of the Interior, Bureau of Sport Fisheries \& Wildlife:

(a) Washington, D.C. 20240

(b) 730 N.E. Pacifie St., Portland, Oregon 97208

Department of the Interior, Bureau of Land Management:

(a) Division of Wildlife, Washington, D.C. 20240

(b) State Director, Federal Bldg., 300 Booth St., Reno, Nevada 89502

Department of the Interior, National Park Sarvice:

(a) Office of Natural Science Studies, Interior Bldg., Washington, D.C. 20240 •

(b) Superintendent, Death Valley National Monument, Death Valley, California 92328 



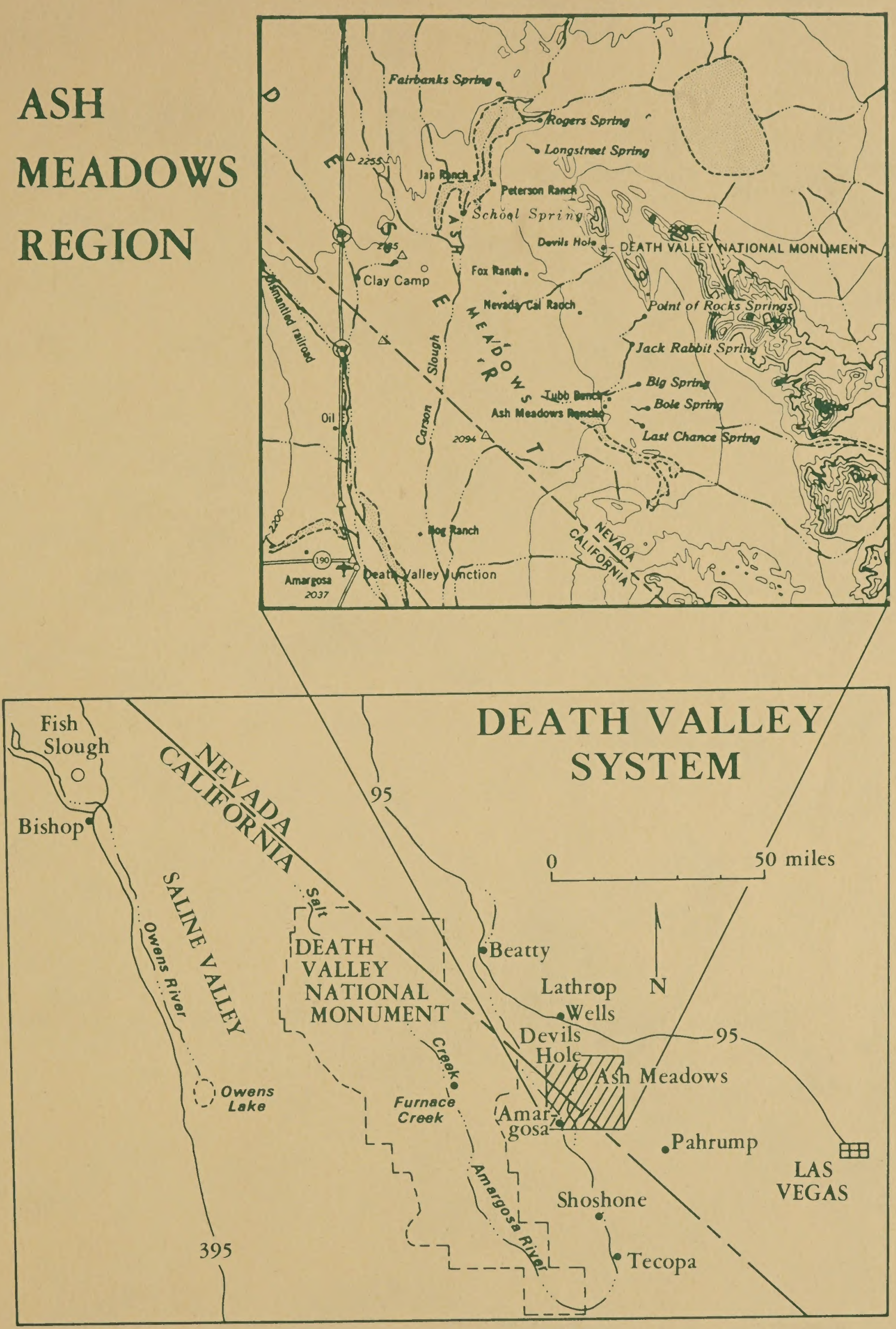

Map of the Death Valley System with an enlargement of the Ash Meadows area. 


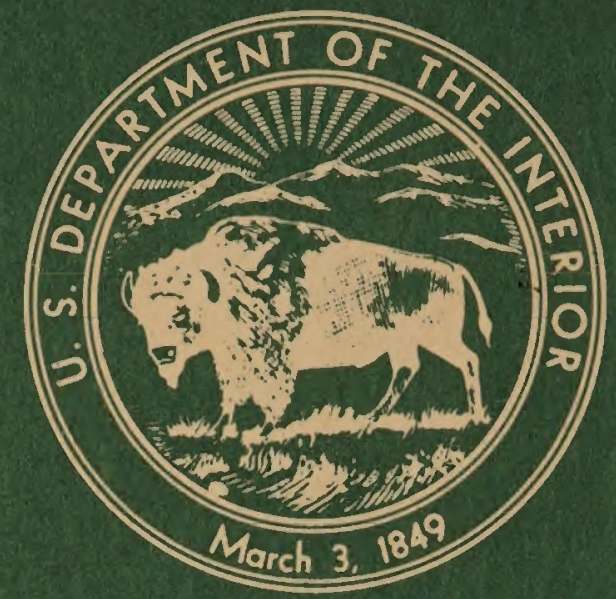

As the Nation's principal conservation agency, the Department of the Interior has basic responsibilities for water, fish, wildlife, mineral, land, park, and recreational resources. Indian and Territorial affairs are other major concerns of this department of natural resources.

The Department works to assure the wisest choice in managing all our resources so that each shall make its full contribution to a better United States now and in the future. 